\title{
Empowering Students' Creativity in Creating Students' Worksheets Using Authentic Materials
}

\author{
Ellisa Indriyani Putri Handayani ${ }^{1}$, Hasan Zainnuri ${ }^{1}$, Moh Salimi $^{2}$ \\ ${ }^{1}$ English Education Department Faculty of Teacher Training and Education, Universitas Sebelas \\ Maret, \\ ${ }^{2}$ Primary Teachers Education Department Faculty of Teacher Training and Education, \\ Universitas Sebelas Maret \\ Jalan Ir. Sutami No. 36 A, Kentingan, Surakarta, Central Java, Indonesia.
}

\begin{abstract}
This paper aims to describe the ability of students in creating and developing students' worksheets using authentic materials. Creating and developing students' worksheets are the final project of those joining English Language Teaching Materials Developments (ELTMDev) class in English Education Department of Teacher Training and Education Faculty in Universitas Sebelas Maret of Surakarta. Not only, should the - would be - teachers learn how to be good teachers, but they also learn how to create and develop good students worksheets suit their students need. This study employs classroom action research. Subjects are ELTMDev students in English Education Department UNS. The findings reveal that: 1) the students' ability in creating and developing students' worksheets increases; 2) the students' understanding in employing authentic materials when creating and developing students' worksheets improves
\end{abstract}

Keywords: students' worksheet; project based learning; materials developments

\section{INTRODUCTION}

Students' worksheets or known as Lembar Kerja Siswa $(L K S)$ are widely used in school as a source of supplementary materials, even as the main source of students activity guidance. It is not an illegal thing for the teachers using students' worksheet in the teaching learning process as long as teachers make sure that all the activities provided in the students' worksheets accordance to the students condition. The activities should suit with the students' level of competence, characteristics, as well as their conditions. Besides, it should also covers all the English proficiencies, like reading, listening, writing, and speaking. Yet, most of the activities provided in it currently focus more on the reading skill only and lack of elaborations and options that can be implemented in every class with different conditions. That is why the teachers must have the competence in creating and developing students' worksheets. In American Heritage Dictionary, the word worksheet is defined as a form with questions or exercises for students. In line with it, in Collins English Dictionary, worksheet is defined as a sheet of paper containing exercises to be completed by a pupil or student. So, worksheets containing questions and exercises here are needed by the students to learn English better. 
In creating and developing worksheets, teachers may make use any sources and any materials as long as suitable with the students need. One of the sources is authentic materials, which are in form of print, video, and audio materials. These materials are encountered by the students in their daily lives, such as change-of address forms, job applications, menus, voice mail messages, radio programs, and videos. They are not intended to be used in the classroom, but they can be used for students precisely because they are authentic (CALPRO-online.org, 2007). Since, there are abundant authentic materials, teachers are expected to be able to select which one is the most appropriate one to be implemented in their classroom. Curriculum and school syllabus are used as the main guidance in choosing or selecting it.

Considering the fact that not only the teachers who must have the ability in creating students worksheet, but also the - would be - teachers who are still in their process of learning of how to be good teachers, the researcher took the chance in giving them the knowledge and experience of how to create and develop students' worksheets using authentic materials. The idea was carried out in the English Language Teaching Material Development (ELTMDev) as one of the subject taught in English Education Department (EED) in Teacher Training and Education Faculty of Sebelas Maret (UNS).

The ELTMDev is a subject intended for the third year students, in their fifth semester. This subject prepares the - would be - teachers of how to evaluate, adapt, create, and develop materials used in schools. Project Based Learning (PBL) is employed to challenge the - would be - teachers in fulfilling and finishing the project given during the teaching learning process, so that they are focus and consciously involved in the process. By implementing the project based learning, the writer make the - would be - teachers fully aware of what kind of project they have to accomplish by the end of the semester.

In Edutopia, Project Based Learning is defined as a dynamic classroom approach in which students actively explore real-world problems and challenges and acquire a deeper knowledge. This definition is strengthen in http://bie.org/about/what_pbl, which defines Project Based Learning as a teaching method, in which students gain knowledge and skills by working for an extended period of time to investigate and respond to an engaging and complex question, problem, or challenge. In Gold Standard PBL, Essential Project Design Elements include:

1. Key Knowledge, Understanding, and Success Skills - The project is focused on student learning goals, including standards-based content and skills such as critical thinking/problem solving, collaboration, and self-management.

2. Challenging Problem or Question - The project is framed by a meaningful problem to solve or a question to answer, at the appropriate level of challenge.

3. Sustained Inquiry - Students engage in a rigorous, extended process of asking questions, finding resources, and applying information.

4. Authenticity - The project features real-world context, tasks and tools, quality standards, or impact - or speaks to students' personal concerns, interests, and issues in their lives.

5. Student Voice \& Choice - Students make some decisions about the project, including how they work and what they create. 
6. Reflection - Students and teachers reflect on learning, the effectiveness of their inquiry and project activities, the quality of student work, obstacles and how to overcome them.

7. Critique \& Revision - Students give, receive, and use feedback to improve their process and products.

8. Public Product-Students make their project work public by explaining, displaying and/or presenting it to people beyond the classroom.

Hence, the - would be - teachers are expected to understand and be fully aware that once they are teachers, they will face different characteristics, conditions, and level of competence of their students. As well as, being able to evaluate, adapt, create, and develop their own materials used in every class. The researcher is going to describe how well the - would be - teachers in trying to create and develop students worksheets using authentic materials by employing their creativity.

\section{METHOD OF THE RESEARCH}

To know how well the - would be - teachers in creating students worksheets using authentic materials, the researcher employed classroom action research. The subjects are the fifth semester students of English Education Department in Teacher Training and Education Faculty UNS joining ELTMDev class. The research was conducted for six months during the whole teaching learning process of a semester.

The action research is the application of fact finding to practical problem solving in a social situation with a view to improve the quality of action within it, involving the collaboration and co-operation of researchers, practitioners, and laymen (Burns, 1999: 30).

Koshy (2005) explains that Classroom Action Research is an enquiry, undertaken with rigour and understanding so as to constantly refine practice; the emerging evidence-based outcomes will then contribute to the researching practitioner's continuing professional development. Kemmis and McTaggart in Koshy (2005: 3-4) describe it as participatory research. The research involves a spiral of self-reflective spirals of: 1) planning a change: instead of conducting the teaching learning process on traditional ways, the researcher started to think of a challenging project as the final project for the students. The researcher set the syllabus and the final project that is creating students' worksheets using authentic materials; 2) acting and observing the process and consequences of the change: in this phase, the researcher acted as the lecturer in ELTMDev subject. While teaching the materials, the researcher asked the students to find the examples of curriculum, school syllabus, and LKS used widely by schools. The researchers asked the students to analyze those sources to be used as the guidance when the students create and develop students' worksheets on their own; 3) reflecting on the processes and consequences and then re-planning: in this phase, the researcher found that the students found it difficult to collect curriculum and schools syllabus, so the researcher as the lecturer provided the examples; 4) acting and observing: here, the researcher observed students activities in planning the final project; 5) reflecting: in this reflecting phase, the researcher made reflection from the whole activities. 


\section{RESULT AND DISCUSSION}

In the initial process, the students were confused because what they knew about students' worksheets was just like what they got in the high schools. A thin uninteresting book consists of many pages of questions that need to be answer whenever the teachers asked them to. They never realized that good worksheets must accordance to their characteristics, conditions, and level of competences. The researcher started to explain the elements that should be considered when teachers intend to create and develop material. The researcher made use the guidelines proposed by Howard and Major (2004). Those guidelines mention that English language teaching materials should be 1) contextualized;2) stimulate interaction and be generative in terms of language; 3) encourage learners to develop learning skills and strategies; 4) allow for a focus on form as well as function; 5) offer opportunities for integrated language use; 6) be authentic; 7) link to each other to develop a progression of skills, understandings and language items; 8) be attractive; 9) have appropriate instructions; and 10) be flexible. However, it was almost impossible for the students to consider all those ten guidelines. The researcher only wanted to make the students (would be teachers) realized that it is necessary for them to learn of how to create and develop students' worksheets.

In order to make the project doable and easier for the students, the researcher divided the class into smaller groups consist of four up to five students. They were then given responsibilities of deciding what subject they were willing to create and develop, analyzing the syllabus, finding the appropriate authentic materials used in the worksheets, designing the layout of the worksheets, planning the activities included in the worksheets, etcetera.

The plus point they own is their creativity in transforming the idea into an outstanding result of the projects. For example, instead of print it on a copied paper, they select more interesting and eye-catching design, even they used sticker paper to replace traditional cut and paste activities. In the writing skill section, the common worksheets will only provide a limited blank paper as the area where the students supposed to write a long letter in the recount genre. Yet, by employing their creativity, the students create a lovely letter paper to make the experience of writing letter in the recount genre more interesting.

Not only focusing on creating and developing the worksheets in the fun ways, the students were also trying to balance the portion of activities covering all the four English proficiencies. Listening skill as one of the skill which is less considered in the common worksheets becomes the most challenging part for the students. They are expected to find the authentic materials to be used in the worksheets. Most of them chose the video or audio from the internet, like from britishcouncil.org and YouTube channels. They, then, adjust and save the audio or video in the CDs enclosed to each worksheet.

Each group must provide fully integrated skill in their worksheets. Thus, unlike common students' worksheets, theirs provide equal portion of reading, writing, listening, as well as speaking. Moreover, those worksheets are printed on selected paper, colorful design, attractive fonts, interesting topics, and enclosed with the audio or video needed in listening session. Although it seemed so fun and interesting, the creation and development of the students' worksheets are still considering the schools 
syllabus and stick to the purpose of providing an excellent supplementary material in the EFL class.

By the end of the research, there were nineteen students' worksheets produced by the students. All those nineteen are satisfying. However, if those worksheets were intended to be printed and published in a wider range, the price would be very competitive. It is because of the better quality and better content offered in it.

\section{CONCLUSION}

Employing students' creativity in creating students' worksheets is not an impossible thing to do although they are not yet real teachers. In fact, it is an activity resulted in both increasing their ability in creating worksheets suit to their students' need and improving their understanding about how to select authentic materials used in it. They also learnt about different syllabus implemented in different schools. It is expected to enrich their knowledge of how to be good teachers by not only conducting teaching learning process, but also creating, adapting, or developing the appropriate materials for their students.

\section{REFERENCES}

[1] American Heritage Dictionary of the English Language ( $5^{\text {th }}$ edition). 2011. Houghton Mifflin Harcourt Publishing Company: Houghton Mifflin Harcourt Publishing Company.

[2] Buck Institute for Education (BIE), http://bie.org/about/what_pbl

[3] Collins English Dictionary: Complete and Unabridged (12 ${ }^{\text {th }}$ edition). 2014. Harper Collins Publisher

[4] Koshy, Valsa. 2005. Action Research for Improving Practice: A Practical Guide. London: Paul Chapman Publishing

[5] http://www.calpro-online.org/documents/AuthenticMaterialsFinal.pdf

[6] http://www.edutopia.org/project-based-learning

[7] http://www.paaljapan.org/resources/proceedings/PAAL9/pdf/Howard.pdf (Guidelines for Designing Effective English Language Teaching Materials by Jocelyn Howard and Jae Major: Christchurch College Institutes) 